Article

\title{
Board Governance, Sustainable Innovation Capability and Corporate Expansion: Empirical Data from Private Listed Companies in China
}

\author{
Peng $X u^{1}$ and Guiyu Bai ${ }^{2, *}$ \\ 1 School of Business Administration, Shandong University of Finance and Economics, Jinan 250014, China \\ 2 Business School, University of Jinan, Jinan 250002, China \\ * Correspondence: sm_baigy@ujn.edu.cn
}

Received: 27 May 2019; Accepted: 22 June 2019; Published: 27 June 2019

check for updates

\begin{abstract}
Within fierce market competition, economic integration acceleration, information technology development, customer demands that are more complex than ever before and product life cycle acceleration have greatly increased the complexity and uncertainty of the operating environment of Chinese private listed companies. Considering the special situation and the current situation of the enterprise development phase in China, the shaping and upgrading of sustainable innovation capability for Chinese private listed companies has become an important issue of common concern in academia and practice. Using 4833 sets of data from private listed companies in China in four consecutive years, we studied the relationship between board governance, sustainable innovation capability and firm expansion empirically based on stewardship theory and principal-agent theory. The results show that centralized leadership structure formed by chief executive officer (CEO) duality has a positive effect on the sustainable innovation capability of Chinese listed companies; director compensation incentive has a positive impact on the sustainable innovation capability of Chinese listed companies; sustainable innovation capability has a positive effect on the firm expansion of Chinese listed companies; and centralized board leadership structure and director compensation incentive have a positive impact on the firm expansion of listed companies partially by improving the sustainable innovation capability.
\end{abstract}

Keywords: Chinese private listed companies; sustainable innovation capability; board leadership structure; director compensation incentives; firm expansion

\section{Introduction}

Relatively low labor costs and land prices used to be the basic guarantee for the rapid development of private enterprises in China. After more than 30 years of development, the private sector has become an important pillar of China's national economy and has made important contributions to the development of China's economy. However, traditional competitive advantages of Chinese private enterprises are difficult to sustain with the gradual disappearance of the demographic dividend and the rising cost of labor and other factors of production [1,2]. In particular, with the transformation of China's economic development from extensive growth to intensive and sustainable development, the operating environment of private enterprises has become full of complexity and uncertainty. Increasing research and development (R\&D) investment and enhancing innovation capability have become effective ways for private enterprises to cope with new competitive situation and achieve sustainable growth in this "new normal" economy [3,4].

However, many factors have brought challenges to the sustainability of private enterprises' innovation, including lack of resources and experience, policy risk of new business development, 
acceptance of the difficulty of product innovation, and relatively weak financing capability $[5,6]$. Against this background, shaping and upgrading of Chinese private enterprises' sustainable innovation capability has become an important issue of common concern for both academia and practical circles.

Corporate governance refers to a set of institutional arrangements that clearly divide the rights, obligations and responsibilities of shareholders (general meeting), board of directors, board of supervisors and managers, and clearly divide the checks and balances between them. Good corporate governance is conducive to improving the scientific decision-making of private listed companies, and is of great significance to enhance the core competitiveness of listed companies and promote their sustainable growth. The board of directors is a decision-making body selected by the shareholders' meeting and the agent company owner is responsible for the command and management of business operations. Its responsibilities mainly include formulating the company's strategic planning, operating objectives, major policies and management principles, and coordinating the relationship between the company and shareholders, management departments and shareholders [7,8]. Board governance aims at improving the efficiency of corporate governance. Based on the characteristics of internal governance, it is of great significance to the composition, operation, power arrangement and allocation mechanism of the board of directors, and to the implementation of innovative decision-making and the formation of innovative ability of listed companies [9,10].

Chinese private listed companies are often faced with the requirements of building a modern enterprise system in view of the particularity of the development process and organizational structure. In recent years in particular, the regulatory system of the Chinese capital market has gradually improved and the regulatory measures become more stringent, which brings more challenges for the optimization of the governance structure and the regulation of the governance system of private listed companies. At the same time, with the scale expansion of institutional investors, the counterbalancing power faced by the actual controllers of private listed companies are enhanced in the process of participating in corporate governance. Thus, board governance plays an increasingly important role in corporate governance mechanism. Furthermore, in the principal-agent system, the voice right and importance of the board of directors in the corporate governance system are further strengthened as some private listed companies suffers intergenerational inheritance crises.

Therefore, according to previous scholars' research [11-14], combined with China's special business situation, this paper chooses two governance elements of board leadership structure and director compensation incentives to analyze the mechanism of board governance influence on the sustainable innovation capability of Chinese private listed companies, and investigates the effect of sustainable innovation capability on firm expansion of Chinese private listed companies. Firm expansion is taken as a dependent variable measured by the growth rate of firms' total assets. The samples of 4833 groups of effective observations were taken into consideration. The time span of the samples includes the years from 2014 to 2017 . The research findings showed that there was significant positive relationship between board leadership structure, director compensation incentives and firm expansion, a significant positive relationship also existed between board leadership structure, director compensation incentives and sustainable innovation capability, and sustainable innovation capability played a mediating role between board leadership structure, director compensation incentives and firm expansion.

This paper finds that centralized board leadership structure and higher compensation incentive will have a positive impact on firms' expansion by enhancing sustainable innovation capability, and clarifies the impact path of board governance on the growth of the company from the level of corporate capacity, which will further enrich the theoretical framework of the value creation effect of board governance Through this study, the governance structure could get some optimized guidance and governance means can be enriched; this study may also provide reference suggestions to promote the sustainable growth in governance practice for Chinese private listed companies.

The remainder of this paper is organized as follows. Section 2 explains the theoretical basis and reviews the empirical literature then proposes the hypothesis on the basis of a literature review. 
Section 3 demonstrates the research design, introduces the samples and data, and the measurement of variables. Section 4 describes the empirical results and discussion include robustness test, and Section 5 is the summary of conclusions, contribution to theory, managerial implications, limitations and suggestions for future research.

\section{Literature Review and Hypothesis Development}

\subsection{Board Governance and Sustainable Innovation Capability}

\subsubsection{Board Leadership Structure and Sustainable Innovation Capability}

Board leadership structure refers to the personnel arrangement of the chief executive officer (CEO) and board chairman of private listed companies. When the two positions are held by one person at the same time, it means that the leadership structure is more centralized and, vice versa, it belongs to relative decentralization leadership structure [15-17]. The choice of the leadership allocation not only reflects the extent to which the board of directors participates in the independent decision-making of corporate governance under the condition of shareholders' check and balances, but also relates to whether the board of directors can supervise and trust the managers, which means the board of directors may not be overridden when they do not interfere in the daily operation of the company. Leadership allocation mode is an important internal governance mechanism for modern companies to coordinate the relationship between shareholders, the board of directors, and managers [18-20].

At present, the empirical research on the board leadership structure in academic circles mainly carries on the analysis from the following two aspects: first, regarding the board leadership structure allocation state as the situational characteristics of the company's operation, and exploring the differences of the governance effects among governance factors, Aylin proposed that a two-position integration leadership structure will weaken the significant positive correlation between corporate profitability and executive compensation [21]. Second, the board leadership structure is taken as an independent variable to explore its influencing mechanism of corporate governance performance and governance behavior. The research of Miller and Yang showed that the concurrent chairman of CEO had a positive impact on the company's valuation [22].

Sustainable innovation is an emerging and fundamental force for change in business and society, which is the key to enhance the core competitiveness of enterprises [23]. It refers to the continuous introduction and implementation of new technological innovation projects (including processes, products, raw materials, organization, management and market, etc.) over a long period of time and the process of realizing the economic benefits of innovation, which should lead to the continual improvement of an enterprise's economic power, technological power, and business scale [24].

In the board governance structure of Chinese private listed companies, it is common for the chairman and general manager to be held by one person. The stewardship theory holds that the board of directors and the managers should develop into a relationship of mutual cooperation and complete trust. The leadership structure of CEO duality will increase the restraint and supervision of the board of directors on the managers, and is not conducive to the managers' due diligence [25,26]. To a certain extent, the leadership structure of CEO duality reflects a kind of "authorization" behavior of the actual controllers of Chinese private listed companies to the agents. Managers are more willing to do a good job of "stewardship" for shareholders because of their own reputation, dignity, career development and pursuit of their own value realization [27,28]. As a result, managers, motivated by their sense of achievement and mission, will take the initiative to complete challenging work and assume responsibility in order to obtain internal satisfaction, such as maintaining a high level of innovation motivation and enthusiasm. Then they incline to implementing more active innovation decisions, and improving the sustainable innovation capability of Chinese private listed companies [29,30]. In addition, CEO duality has formed a relatively centralized leadership structure, which not only has a positive impact on reducing the communication time of internal decision-making and reducing the differences between the board of directors and the managers, but also helps managers to integrate the 
strategic decision-making capital of executive directors and non-executive directors which makes the knowledge and experience of the board of directors and managers easier to transfer and transform within the company [31]. Faced with the fierce changing market environment, it can also make an innovative response quickly, improve the efficiency and effect of innovative decision-making, and have a positive impact on the shaping of sustainable innovation capability of listed companies. Based on this, we suggest the following hypothesis:

Hypothesis 1. Within the Chinese context, centralized leadership structure formed by CEO duality has a positive effect on sustainable innovation capability of Chinese private listed companies.

\subsubsection{Director Compensation Incentives and Sustainable Innovation Capability}

Compensation incentives are one of the main ways to motivate board members in governance practice. Compensation refers to the company's labor remuneration to board members [32]. Many scholars have studied the positive role of board compensation incentives on corporate governance from different perspectives. Research by Yermack [31] shows that there is a significant positive correlation between external directors' compensation and corporate performance, and this positive correlation is not limited to enterprises with performance difficulties. Based on reviewing and sorting out of existing relevant research, the different levels of directors compensation incentives of private listed companies will lead to different directors' governance attitudes and behaviors, and this difference will have an impact on the cultivation of sustainable innovation capability of listed companies $[33,34]$. Specific performance: principal-agent theory holds that compensation incentives can effectively restrain the opportunistic behavior of agents, so that the interests of agents and principals can in accordance with each other $[35,36]$. When directors can get relatively high compensation, they may pay more attention to the long-term development of the company in order to ensure the current income level and position, and then they will be willing to implement a positive innovation strategy and provide conditions for shaping the sustainable innovation capability of their listed companies. In particular, equity incentives for top managers and core employees of enterprises will directly contribute to the improvement of enterprises' sustainable innovation capability by improving corporate governance's awareness of innovation and reducing the "shortsightedness" of the principal-agent. It can be seen that, to a large extent, the equity ratio index of senior managers and core employees can determine the capability of sustainable innovation. However, work slack will appear when directors' compensation is relatively low, and the enthusiasm of board members will be greatly weakened, which will make listed companies more likely to suffer slow action when facing competitors' competitive behavior [37]. In the market competition, there is a serious lack of motivation to implement positive innovation decision-making, which is not conducive to the improvement of sustainable innovation capability of Chinese private listed companies. Based on this, we propose the following hypothesis:

Hypothesis 2. Within the Chinese context, compensation of board members has a positive effect on sustainable innovation capability of Chinese private listed companies.

\subsection{Sustainable Innovation Capability and Firm Expansion}

Firm expansion refers to the growth of the companies' scale or assets, which belongs to the growth dimension of listed companies as well as profitability [38]. Firm expansion emphasizes the sustainable development of listed companies. The effect paths of sustainable innovation capability on firm expansion are as follows: firstly, sustainable innovation capability is an important condition for enterprises to enhance market share through market competition or changing the market competition pattern, providing motive force and opportunity for the expansion of listed companies [39]. In particular, the characteristics of difficult imitation and response of sustainable innovation capability provide listed 
companies more room for strategic choice in market competition, which lays the foundation for the company's scale expansion [40,41]. Secondly, in addition to the active acquisition of market share, sustainable innovation capability is also an important guarantee for listed companies to cope with the aggression of competitors. As a scarce resource in company development, sustainable innovation capability has a positive impact on the rational allocation and reorganization of enterprise resources in time and space, which is conducive to maximizing the utility of resources and making quick and effective response to opponent's aggression when facing fierce competition. It has positive significance for consolidating the company's competitive advantage and maintaining its expansion speed [42,43]. Based on the above analysis, we suggest the third hypothesis:

Hypothesis 3. Within the Chinese context, sustainable innovation capability has a positive effect on firm expansion of Chinese private listed companies.

\subsection{Mediating Role of Sustainable Innovation Capability}

As mentioned above, sustainable innovation refers to the continuous introduction and implementation of new technological innovation projects (including processes, products, raw materials, organization, management and market, etc.) over a long period of time and the process of realizing the economic benefits of innovation, which should lead to the continual improvement of an enterprise's economic power, technological power, and business scale [24]. Sustainable innovation capability is especially important for companies in an intense global competition environment. Board leadership structure of CEO duality makes managers of Chinese private listed companies tend to implement relatively positive innovation strategies based on the mentality of stewardship, and have higher autonomy in strategic decision-making [44,45]. Director compensation incentive can alleviate the risk-aversion tendency of board members in innovation decision-making and improve their innovation initiative [46]. Sustainable innovation capability gives listed companies strong advantages in improving market share and coping with market competition, which is conducive to company expansion [47]. Based on the above analysis and the literature review, we find board governance will affect the expansion of Chinese private listed companies by affecting sustainable innovation capability. Thus, we propose the mediating hypothesis of sustainable innovation capability as follows:

Hypothesis 4a. Within the Chinese context, relatively centralized board leadership structure has a positive impact on the expansion of listed companies by enhancing sustainable innovation capability of Chinese private listed companies.

Hypothesis $\mathbf{4 b}$. Within the Chinese context, director compensation incentives have a positive impact on the expansion of listed companies by improving the sustainable innovation capability of Chinese private listed companies

The overall study model is shown in Figure 1.

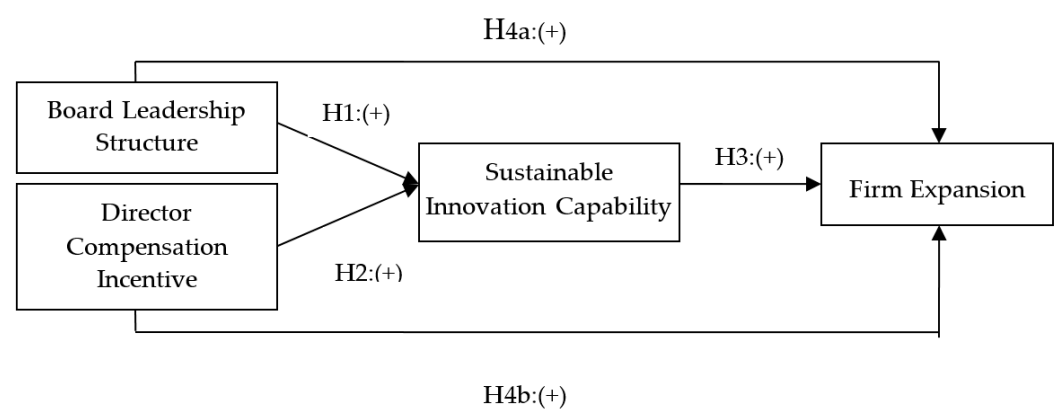

Figure 1. Hypothesized model. 


\section{Research Design}

\subsection{Samples and Data}

This paper took Chinese private listed companies as the object to study the promoting mechanism and effect of sustainable innovation capability based on the board governance perspective. Firstly, it screened out the private capital listed companies that actually control by persons or families. Secondly, the sample observation period was determined from 2014 to 2017, so it chose the companies listed before 31 December 2013 and made sure that the observation objects had no major restructuring events and had never enjoyed "Special Treatment" (ST) and "ST (stocks that have been warned of delisting risks) during the sample observation period; the companies whose data were seriously missing were all deleted in this study. (Special Treatment refers to the stocks of domestic listed companies that are specially treated. In China, The Shanghai and Shenzhen Stock Exchange announced that special treatment will be given to the stock transactions of listed companies with abnormal financial and other financial conditions. The abnormality mainly refers to two situations: one is that the net profit of listed companies in two audited fiscal years is negative; the other is that the net assets per share audited by listed companies in the last fiscal year are lower than the face value of stocks. *ST shares refer to those stocks that have been warned of delisting risks by listed companies in China after two consecutive years of losses. Some *ST-listed companies through their own efforts, are expected to take off the company's loss cap, and some will be delisted. "Seriously missing" refers to situation when sample companies' data used to measure the dependent variables, independent variables or mediating variables cannot be found in any way. If such data are not found, it will directly mean variables cannot be measured correctly. In general, the treatment of missing data can be divided into deleting cases with missing values and missing interpolation. Simple deletion is the most original method to deal with missing values. It will delete cases with missing values. Then we can achieve the research goal simply by deleting a small number of samples.) Finally, 4833 groups of effective observation samples were selected, including 1198 groups in 2014, 1209 groups in 2015, 1213 groups in 2016 and 1213 groups in 2017. The relevant data used in this empirical analysis were all from the CSMAR database (CSMAR database is an economic and financial database developed from the needs of academic research). The sample screening process is in Table 1.

Table 1. Sample screening process.

\begin{tabular}{lccc}
\hline & Number of Observations & \multicolumn{2}{c}{ Specific Distribution } \\
\hline & & 2014 & 2395 \\
Listed Companies Controlled by & 9580 & 2015 & 2395 \\
Families or Natural Persons & & 2016 & 2395 \\
& & 2017 & 2395 \\
& \multirow{2}{*}{6104} & 2014 & 1526 \\
Listing date expires 31 December 2013 & & 2015 & 1526 \\
& & 2016 & 1526 \\
Elimination of major reorganization, & \multirow{2}{*}{4833} & 2017 & 1526 \\
ST and *ST, serious data missing & & 2014 & 1198 \\
& & 2015 & 1209 \\
& & 2016 & 1213 \\
\hline
\end{tabular}

Notes: ST refers to the stocks of domestic listed companies that are specially treated; ${ }^{*}$ ST refers to stocks of domestic listed companies that have been warned of delisting risks.

\subsection{Variables and Measurements}

\subsubsection{Dependent Variable}

Nyberg and Pöyry [38] studied the relationship between firm expansion and stock price momentum, and they used aggregate asset growth to measure firm expansion, on the basis of their achievements 
and then according to Fu, Ke and Huang [48]. The improvement effect of sustainable innovation capability can be observed by firm expansion, which was measured by the growth rate of firms' total assets. The growth rate of total assets is the ratio of the total assets at the end of the year to the total assets at the beginning of the year. The growth of total assets in this year is the difference between the end of the year and the beginning of the year. It is the main index to analyze the capital accumulation and development ability of enterprises in that year.

\subsubsection{Independent Variables}

From the perspective of board governance, this paper analyzed the enhancement path of sustainable innovation capability. There were many indicators of board governance as Nkundabanyanga [49] adopted first-hand data to measure board governance whose item scales consistent with the Institute of Corporate Governance of Uganda's manual on corporate governance. Seijts et al. [50] studied the leader character indicator of board governance. Thus, in order to meet the research requirement, in this paper independent variables were board leadership structure and director compensation incentives, which were two dimensions of board governance. The specific measurement methods were as follows: according to Kang and Zardkoohi [51], board leadership structure was measured by the part-time situation of chairman and CEO, which was also named CEO duality. During the study of CEO duality, agency costs, and internal capital allocation efficiency, Aktas et al. [52] thought that CEO duality was a dummy variable set equal to one for firm-years during which the CEO served also as the board chair, and zero otherwise. According to their study, board leadership structure was measured using the same method, when two positions were held by one person, this indicator was marked as " 1 ", which was regarded as a relatively centralized leadership structure, otherwise this indicator was marked as " 0 ". According to Doucouliagos, Haman and Askary [53], directors' remuneration was measured by the proportion of the top three directors' total salary to the total operating cost of the firm in that year.

\subsubsection{Mediating Variable}

This paper studied the causes and results of sustainable innovation capability of Chinese private listed companies, and then examined the mediating role of sustainable innovation capability in the relationship between board governance and enterprise expansion. Firms may have planned to develop a new product or process to improve their productivity, reduce costs and reduce environmental pollution with a high degree of sustainable innovation ability [54]. On the measurement of sustainable innovation capability, according to Hall [55], intangible assets [56], including patents [57], non-patented technologies [58], trademarks [59] and copyrights were the elements of enterprise innovation sustainability activities, so we used the growth rate of intangible assets for mediating variable measurement.

\subsubsection{Control Variable}

According to Kung and Ma [60], some other variables may also have a relationship with enterprise expansion, so some variables were chosen as control variables in this paper; the control variables include the firm size [61], capital structure, ownership concentration, capital preservation and appreciation rate, working capital turnover rate and three year control variables. Firm size largely reflects the state of firms' disposable resources, and has a significant impact on sustainable innovation capability and expansion [62]. Referring to previous studies, we measure firm size from the number of employees [63]. Because of the difference of data magnitude, we take logarithm of the original data of the indicator in empirical analysis. Capital structure is another control variable, which mainly referred to the composition and proportion of various long-term capital, which will greatly affected the innovation investment and business decision-making of enterprises [64]. According to the previous studies, capital structure was measured by debt ratio (total debt to total assets). Ownership concentration is the basic index to weigh the ownership structure of listed companies. Previous studies have proved that the ownership structure of listed companies has an important impact on business decision-making [65]. 
Therefore, this paper chose it as one of the control variables and measured it by the proportion of controlling shareholders in the company. The ratio of the final value of the total owner's equity to the initial value of the total owner's equity is used to measure capital preservation and appreciation rate. Working capital turnover rate is measured by the ratio of operating income to working capital. The annual measurements are three control variables. Definition and measurement of variables are shown in Table 2:

Table 2. Definition and measurement of variables.

\begin{tabular}{|c|c|c|}
\hline Variables & Code & Index \\
\hline Director compensation incentives & DCI & $\begin{array}{l}\text { Proportion of the top three directors' total salary to the total } \\
\text { operating cost of the firm in that year. }\end{array}$ \\
\hline Sustainable innovation capability & SIC & Growth rate of intangible assets. \\
\hline Firm size & FS & The number of employees \\
\hline Capital structure & CS & Debt ratio. \\
\hline Ownership concentration & $\mathrm{OC}$ & Proportion of controlling shareholders. \\
\hline $\begin{array}{l}\text { Capital preservation and } \\
\text { appreciation rate }\end{array}$ & CPAR & $\begin{array}{l}\text { The ratio of the final value of the total owner's equity to the } \\
\text { initial value of the total owner's equity. }\end{array}$ \\
\hline Working capital turnover rate & WCTR & The ratio of operating income to working capital. \\
\hline
\end{tabular}

\subsection{Models}

To investigate the impact of board governance on firm expansion and the mediating effect of sustainable innovation capability between this relationship, we proposed the following model:

Model (1)-(2) is utilized to investigate the relationship between board leadership structure, director compensation incentives and sustainable innovation capability. Models (3)-(6) are utilized to investigate the relationship between independent variables and firm expansion and the mediating effect of sustainable innovation capability.

$$
\begin{gathered}
\text { SIC }=c+\sum_{j=1}^{8} b_{j} \text { Control }+\varepsilon \\
\text { SIC }=c+\sum_{j=1}^{8} b_{j} \text { Control }+a_{1} B L S+a_{2} D C I+\varepsilon \\
F E=c+\sum_{j=1}^{8} b_{j} \text { Control }+\varepsilon \\
F E=c+\sum_{j=1}^{8} b_{j} \text { Control }+a S I A+\varepsilon \\
F E=c+\sum_{j=1}^{8} b_{j} \text { Control }+a_{1} B L S+a_{2} D C I+\varepsilon \\
F E=c+\sum_{j=1}^{8} b_{j} \text { Control }+a_{1} B L S+a_{2} D C I+a_{3} \text { SIC }+\varepsilon
\end{gathered}
$$


where control represents the control variables group, $c$ is the intercepting term, $\varepsilon$ denotes the measurement error term, $j$ is the serial number of each control variable, $b_{j}$ stands for the regression coefficients of each control variable, and a stands for the regression coefficients of each independent variable.

\section{Empirical Results}

\subsection{Descriptive Statistics}

Table 3 shows the descriptive statistics for the independent and dependent variables. In order to avoid the influence of sample outliers, this paper uses STATA software to tail all continuous variables up and down by $5 \%$. Descriptive statistics and multiple regression analysis are carried out with the processed data. The results of descriptive statistics of the main variables in this paper are shown in Table 3. The average value of board leadership structure during the observation period is between 0.387 and 0.392 , and the overall change is not significant. This shows that about $40 \%$ of the private listed companies in China adopt a relatively centralized leadership structure. In the study of corporate governance, principal-agent theory is generally accepted. Many researchers regard the separated leadership structure as a better governance structure. They believe that if the general manager has greater power in the company, the independence of the board of directors is difficult to maintain. However, in an actual operating company, CEO duality is very common. The statistical data in this paper shows that about $40 \%$ of the private listed companies in China adopt a relatively centralized leadership structure. The reasons may as follows: Firstly, the corporate governance system in China started relatively late and is not perfect at present; secondly, influenced by Chinese traditional culture, many enterprises adopt a culture-adapted governance structure; many founders of family businesses are conservative and worry about the reduction of control rights. The average and median changes of director compensation incentives show that the director compensation incentive intensity of China's private listed companies is gradually declining. At the same time, the range of maximum and minimum compensation incentives is large, which indicates that there are great differences in board members' incentive levels among different samples. The standard deviation and extreme value of sustainable innovation capability reflect the great differences between the sustainable innovation capabilities of different private listed companies. It is also found that the value of sustainable innovation capability of many samples is less than 0 in each year combining the median description results, and such enterprises should strengthen the cultivation and shaping of sustainable innovation capability and pay attention to the acquisition of long-term competitive advantage of companies. The descriptive results of expansion show that the mean value is larger than the median value, which indicates that expansion level of most private listed companies is not satisfied, and also that the sample companies are quite different, and some companies should strive to strengthen their capability to sustain expansion.

Table 3. Descriptive statistics of variables.

\begin{tabular}{cccccccc}
\hline \multirow{6}{*}{2014} & Variable & Mean & Standard Deviation & Minimum & Maximum & Median & N \\
\hline \multirow{6}{*}{2015} & BLS & 0.388 & 0.488 & 0.000 & 1.000 & 0.000 & 1198 \\
& DCI & 0.002 & 0.001 & 0.000 & 0.004 & 0.001 & 1198 \\
& SIC & 0.187 & 0.359 & -0.140 & 1.022 & 0.009 & 1198 \\
& FE & 0.178 & 0.206 & -0.054 & 0.643 & 0.119 & 1198 \\
& BLS & 0.392 & 0.488 & 0.000 & 1.000 & 0.000 & 1209 \\
& DCI & 0.002 & 0.001 & 0.000 & 0.004 & 0.001 & 1209 \\
& SIC & 0.212 & 0.379 & -0.140 & 1.022 & 0.021 & 1209 \\
& FE & 0.209 & 0.233 & -0.054 & 0.643 & 0.132 & 1209 \\
& BLS & 0.388 & 0.488 & 0.000 & 1.000 & 0.000 & 1213 \\
& DCI & 0.001 & 0.001 & 0.000 & 0.004 & 0.001 & 1213 \\
& SIC & 0.184 & 0.364 & -0.140 & 1.022 & 0.015 & 1213 \\
& FE & 0.211 & 0.232 & -0.054 & 0.643 & 0.132 & 1213 \\
& BLS & 0.387 & 0.487 & 0.000 & 1.000 & 0.000 & 1213 \\
& DCI & 0.001 & 0.001 & 0.000 & 0.004 & 0.001 & 1213 \\
& SIC & 0.142 & 0.336 & -0.140 & 1.022 & -0.010 & 1213 \\
& FE & 0.171 & 0.197 & -0.054 & 0.643 & 0.114 & 1213 \\
\hline
\end{tabular}




\subsection{Regression Results}

Table 4 provides the results of the regression analysis for testing our hypotheses. Sustainable innovation capability (SIC) was the dependent variable employed in Model 1 and Model 2 to test the first two hypotheses. In Model 1, we examined relationship between control variables and sustainable innovation ability (SIC), on the basis of Model 1, we added independent variables that included board leadership structure (BLS) and director compensation incentives (DCI) into Model 2, which showed that board leadership structure (BLS) $(\mathrm{a} 1=0.024 ; p<0.1$; model 2$)$ and director compensation incentives (DCI) ( $a 2=0.060 ; p<0.01$; model 2$)$ were positively influenced by sustainable innovation capability (SIC) at the $1 \%$ level of confidence and $10 \%$ level of confidence respectively, thus supporting Hypothesis 1 and Hypothesis 2. The results of this area can also be extended and applied to explain corporate divestment and unpalatable decisions of firms [66].

In Model 3 and Model 4, firm expansion (FE) was the dependent variable; these two models tested the relationship between sustainable innovation capability (SIC) and firm expansion (FE). Regression results demonstrated that sustainable innovation capability positively influenced firm expansion (a3 $=0.336 ; p<0.01$; Model 4 ) at the $1 \%$ level of confidence. Thus, this result supports Hypothesis 3 , and it is in accord with the results of study on innovation capability and firm growth from many other research works [67].

Model 5 was used to test the relationship between independent variables included board leadership structure (BLS) and director compensation incentives (DCI) and dependent variable firm expansion (FE), results shown in Table 4 demonstrated that there were significantly positive relationships between board leadership structure and firm expansion ( $\mathrm{a} 1=0.038 ; p<0.01$; model 5$)$, and significantly positive relationships between director compensation incentives and firm expansion ( $\mathrm{a} 2=0.050 ; p<0.01$; model 5).

In Model 6, we added the mediating variable, and the results verified the mediating effect of sustainable innovation capability ( $\mathrm{a} 3=0.334 ; p<0.01$; model 6 ) between board leadership structure (a1 $=0.030 ; p<0.01$; model 6$)$, director compensation incentives ( $1=0.030 ; p<0.01$; model 6 ) and firm expansion. Thus, this result supports Hypothesis 4; the effect of independent variables of firm expansion was partially realized by the improvement of sustainable innovation ability.

Considering the possible problem of heteroscedasticity, each model reports the results of robust standard error regression (the second column of each model). The results of the study are consistent with OLS(Ordinary Least Square) regression results. It shows that even considering the problem of heteroscedasticity, the hypotheses proposed in this paper have been verified, See Table 5 for details. 
Table 4. Regression results.

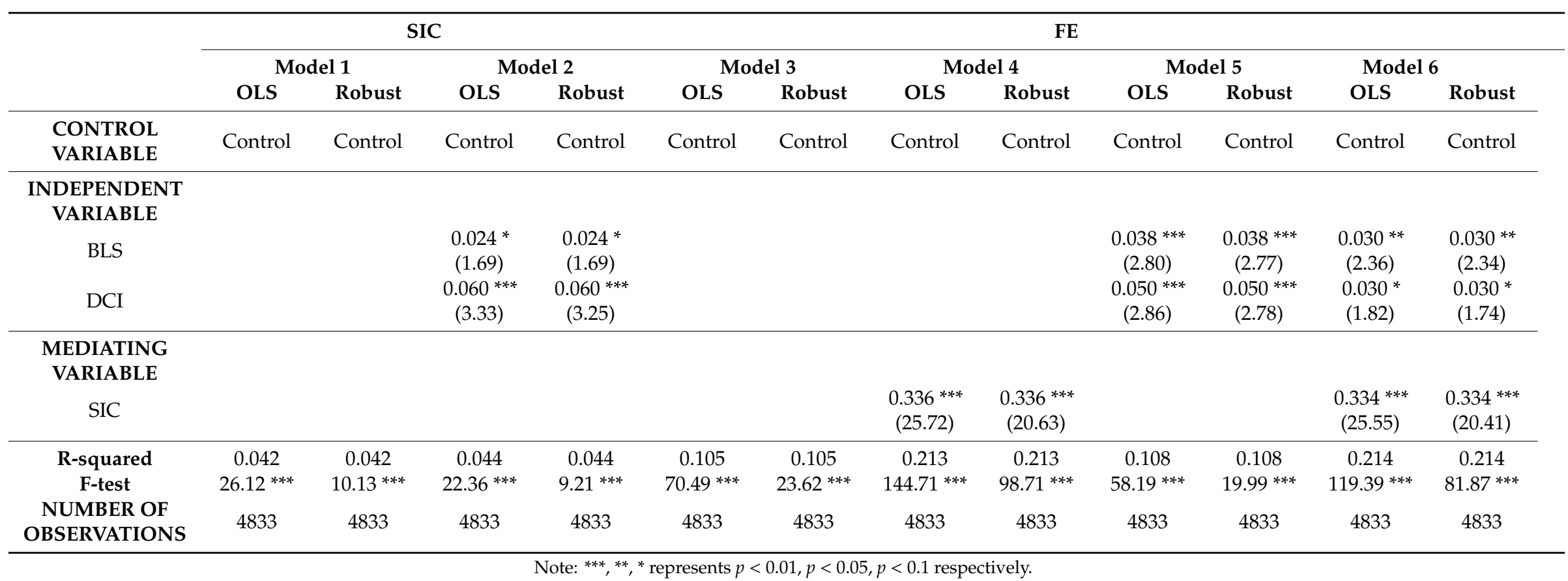


Table 5. Hypotheses and whether hypotheses are verified.

\begin{tabular}{|c|c|c|}
\hline & Hypotheses & $\begin{array}{l}\text { Whether Hypotheses } \\
\text { Are Verified }\end{array}$ \\
\hline Hypothesis 1 & $\begin{array}{l}\text { Within the Chinese context, centralized leadership structure } \\
\text { formed by CEO duality has a positive effect on sustainable } \\
\text { innovation of Chinese private listed companies. } \\
\text { Within the Chinese context, compensation of board members }\end{array}$ & YES \\
\hline Hypothesis 2 & $\begin{array}{l}\text { has a positive effect on sustainable innovation of Chinese } \\
\text { private listed companies. }\end{array}$ & YES \\
\hline Hypothesis 3 & $\begin{array}{l}\text { Within the Chinese context, sustainable innovation capability } \\
\text { has a positive effect on firm expansion of Chinese private } \\
\text { listed companies. }\end{array}$ & YES \\
\hline Hypothesis 4a & $\begin{array}{l}\text { Within the Chinese context, relatively centralized board } \\
\text { leadership structure has a positive impact on the expansion of } \\
\text { listed companies by enhancing sustainable innovation } \\
\text { capability of Chinese private listed companies. }\end{array}$ & YES \\
\hline Hypothesis $4 b$ & $\begin{array}{l}\text { Within the Chinese context, director compensation incentives } \\
\text { have a positive impact on the expansion of listed companies } \\
\text { by improving their sustainable innovation capability of } \\
\text { Chinese private listed companies. }\end{array}$ & YES \\
\hline
\end{tabular}

\subsection{Robustness Check}

To ensure robustness, we analyzed two aspects: endogenous problems and the method of explanatory variable measurement substitution $[68,69]$.

(1) Consider possible endogenous problems

Considering that there are doubts about the endogeneity of the explanatory variables (DCI) in this study, the economic development level (gross domestic product) of the area where the company is located was used as a tool variable, using the OLS to analyze and carry out a Hausman test. The results of Table 6 show that the p-value of Hausman test is greater than 0.05 in both the regression of mediating variables to explanatory variables and the regression of dependent variables to explanatory variables, and the exogenous assumption of DCI cannot be rejected. The above results show that the model has no serious endogenous problems.

Table 6. Endogeneity check.

\begin{tabular}{ccc}
\hline & IV $\rightarrow$ MV & IV $\rightarrow \mathbf{D V}$ \\
\hline Chi-square statistic & 0.28 & 0.17 \\
$p$-value & 0.5980 & 0.6783 \\
\hline
\end{tabular}

\section{(2) Substitution of key variables}

Substitution of key variables: one is the board leadership structure; the other is the director compensation incentives. The director leadership structure is replaced by "whether the actual controller acts as the chairman of the company". When the actual controller acts as the chairman of the company, the actual controller of the listed company will have stronger leadership because of the ownership. Therefore, it is reasonable to measure the centralization degree of the leadership structure by replacing the two-position integration. The measurement of the dependent variable is changed from the growth rate of total assets to the growth rate of fixed assets.

Regression results of four models for robustness test are as follows in Table 7. The coefficients of substitution explanatory variables are all positive and significant in the models:

a1 $=0.111 ; p<0.01 ;$ model 1, a2 $=0.062 ; p<0.01 ;$ model $1, \mathrm{a} 1=0.126 ; p<0.01 ;$ model $2, \mathrm{a} 2=0.050 ;$ $p<0.01$; model 2, a1 $=0.010 ; p<0.01$; model 4 , a2 $=0.036 ; p<0.05$; model 4 , a3 $=0.232 ; p<0.01$; model 4. Thus, the results of Table 7 also align with our main findings. 
Table 7. Regression results: robustness test.

\begin{tabular}{|c|c|c|c|c|c|c|c|c|}
\hline & \multicolumn{2}{|c|}{ SIC } & \multicolumn{6}{|c|}{$\mathrm{FE}$} \\
\hline & OLS & Robust & OLS & Robust & OLS & Robust & OLS & Robust \\
\hline $\begin{array}{l}\text { CONTROL } \\
\text { VARIABLE }\end{array}$ & Control & Control & Control & Control & Control & Control & Control & Control \\
\hline \multicolumn{9}{|l|}{$\begin{array}{l}\text { INDEPENDENT } \\
\text { VARIABLE }\end{array}$} \\
\hline BLS & $\begin{array}{c}0.111^{* * *} \\
(7.84)\end{array}$ & $\begin{array}{c}0.111^{* * *} \\
(8.55)\end{array}$ & $\begin{array}{c}0.126^{* * *} \\
(8.81)\end{array}$ & $\begin{array}{c}0.129 * * * \\
(7.51)\end{array}$ & & & $\begin{array}{c}0.010^{* * *} \\
(7.15)\end{array}$ & $\begin{array}{c}0.100 * * * \\
(7.58)\end{array}$ \\
\hline DCI & $\begin{array}{c}0.062 * * * \\
(3.46) \\
\end{array}$ & $\begin{array}{c}0.062 * * * \\
(3.39) \\
\end{array}$ & $\begin{array}{c}0.050 * * * \\
(2.78)\end{array}$ & $\begin{array}{c}0.046^{* * *} \\
(2.87)\end{array}$ & & & $\begin{array}{c}0.036^{* *} \\
(2.04)\end{array}$ & $\begin{array}{c}0.036^{* *} \\
(1.98) \\
\end{array}$ \\
\hline \multicolumn{9}{|l|}{$\begin{array}{l}\text { MEDIATING } \\
\text { VARIABLE }\end{array}$} \\
\hline SIC & & & & & $\begin{array}{c}0.245^{* * *} \\
(17.45)\end{array}$ & $\begin{array}{c}0.245^{* * *} \\
(15.10)\end{array}$ & $\begin{array}{c}0.232 * * * \\
(16.52)\end{array}$ & $\begin{array}{c}0.232 * * * \\
(14.08)\end{array}$ \\
\hline $\mathrm{R} 2$ & 0.056 & 0.056 & 0.049 & 0.049 & 0.090 & 0.090 & 0.100 & 0.100 \\
\hline F_Value & $28.48 * * *$ & $16.15^{* * *}$ & $25.03^{* * *}$ & $22.51^{* * *}$ & $53.01^{* * *}$ & $45.02 * * *$ & $48.83^{* * *}$ & $44.41^{* * *}$ \\
\hline $\begin{array}{l}\text { NUMBER OF } \\
\text { OBSERVATIONS }\end{array}$ & 4833 & 4833 & 4833 & 4833 & 4833 & 4833 & 4833 & 4833 \\
\hline
\end{tabular}

\section{Conclusions and Enlightenment}

\subsection{Research Conclusions}

Based on the stewardship theory and principal-agent theory, this paper analyses ways to improve the sustainable innovation capability of Chinese private listed companies from the perspective of board governance, and investigates the impact of sustainable innovation capability on firm expansion. The results show that: first, centralized board leadership structure is conducive to the sustainable innovation capability of listed companies; second, director compensation incentive has a positive impact on the sustainable innovation capability of listed companies; third, sustainable innovation capability is conducive to enhancing the expansion of listed companies; and fourth, centralized board leadership structure and director compensation incentives will have a positive impact on the expansion of listed companies by improving sustainable innovation capability.

\subsection{Contribution to Theory}

Firstly, as the highest decision-making organ of corporate governance, there are many debates about the adaptability of centralized and decentralized leadership structures. This paper takes sustainable innovation capability as the explanatory variable to verify the positive role of centralized leadership structure in corporate governance, and provides further theoretical support for relevant research in this field. At the same time, previous academic studies have examined the governance effectiveness of the board of directors from the aspects of operating performance, company value and so on. This paper finds that a centralized board leadership structure and higher compensation incentive will have a positive impact on the firm's expansion by enhancing sustainable innovation capability, and clarifies the impact path of board governance on the growth of the company from the level of corporate capacity, which will further enrich the theoretical framework of the value creation effect of board governance.

Secondly, regarding enterprise innovation, many scholars have studied the innovation behavior mechanism of the enterprise level [70] and employee level [71] from the perspective of strategic management or organizational behavior in the past. However, due to the changing external institutional environment and competitive situation, the positive significance of innovation behavior to the sustainable development of enterprises is uncertain. There are also some disputes about the academic value of the research on the antecedents of innovation behavior. Unlike innovative behavior, 
sustainable innovation capability is the embodiment of deterministic core competence for enterprise development [72]. This paper also confirms its positive role in the process of sustainable growth of enterprises, and has a certain reference value for future theoretical research on the shaping and upgrading mechanism of sustainable innovation capability for enterprises.

\subsection{Managerial Implications}

Private listed companies in China have the characteristics of relatively centralized ownership and high participation of actual controllers, which makes the agent subject to strong constraints from the principal in corporate governance. Moreover, by contrast with state-owned enterprises, there is a lack of a "political championship" mechanism in private listed companies [73,74]. As a result, agents are more likely to consider their long-term position and economic reward when making decisions on innovative strategies with high risks. Based on the perspective of board governance in a corporate governance system, this paper analyses the path of sustainable innovation capability enhancement. The conclusion further illustrates that in order to enhance sustainable innovation capability, private listed companies should empower their agents properly and strengthen compensation incentives, so as to enhance core competitiveness and product profitability space, and lay a solid foundation for the long-term sustainable development of enterprises. Relevant research conclusions can also provide reference and guidance for private listed companies to optimize governance structure and improve governance system in practice.

\subsection{Limitations and Suggestions for Future Research}

There are still some limitations in this study, which need to be further enriched and improved upon in future research. Firstly, although this paper verifies the positive role of board leadership structure and compensation incentives in sustainable innovation capability, it has not yet analyzed the effect of the differentiated board structure (such as board size, board education, gender, past experience, etc.) in the above relationship. Secondly, the sustainable innovation capability and expansion of listed companies are affected by many aspects of organizational operation mechanism. Whether there are many other factors that have an important influence on the formation of sustainable innovation capability, and whether there is interaction with board governance, are worthy of further investigation and exploration in future research.

Author Contributions: Conceptualization, P.X. and G.B.; Data curation, P.X.; Formal analysis, P.X. and G.B.; Funding acquisition, P.X.; Investigation, P.X.; Methodology, P.X.; Project administration, G.B.; Supervision, G.B.; Validation, P.X.; Visualization, P.X. and G.B.; Writing-original draft, G.B.; Writing-review and editing, P.X. and G.B.

Funding: The authors gratefully acknowledge the support from National Natural Science Foundation of China (grant no. 71602099), Natural Science Foundation of Shandong Province (grant no. ZR2018QG003), and Natural Science Foundation of Shandong Province (grant no. ZR2016GQ04).

Conflicts of Interest: The authors declare no conflict of interest.

\section{References}

1. Liang, X.; Lu, X.; Wang, L. Outward internationalization of private enterprises in China: The effect of competitive advantages and disadvantages compared to home market rivals. J. World Bus. 2012, 47, $134-144$. [CrossRef]

2. Badi, S.; Wang, L.; Pryke, S. Relationship marketing in Guanxi networks: A social network analysis study of Chinese construction small and medium-sized enterprises. Ind. Mark. Manag. 2017, 60, 204-218. [CrossRef]

3. Song, M.; Ai, H.; Xie, L. Political connections, financing constraints, and the optimization of innovation efficiency among China's private enterprises. J. Technol. Forecast. Soc. 2015, 92, 290-299. [CrossRef]

4. Xie, T.; Zhou, G.; Zheng, S. The Support System of Innovation-Driven Strategy in Private Enterprises: A Theoretical Model. In International Conference on Management Science and Engineering Management; Springer: Cham, Switzerland, 2017; pp. 825-834. 
5. Cheng, L.; Lei, Z. Does the expansion of Chinese state-owned enterprises affect the innovative behavior of private enterprises? Asia Pac. J. Account. Econ. 2015, 22, 24-54. [CrossRef]

6. Nanda, R.; Rhodes-Kropf, M. Financing risk and innovation. Manag. Sci. 2016, 63, 901-918. [CrossRef]

7. Baysinger, B.D.; Butler, H.N. Corporate Governance and the Board of Directors: Performance Effects of Changes in Board Composition. J. Law Econ. Organ. 1985, 1, 101-124.

8. Ertimur, Y.; Ferri, F.; Stubben, S.R. Board of directors' responsiveness to shareholders: Evidence from shareholder proposals. J. Corp. Financ. 2010, 16, 53-72. [CrossRef]

9. Shaukat, A. Trojanowski, G. Board governance and corporate performance. J. Bus. Financ. Account. 2018, 45, 184-208. [CrossRef]

10. Desender, K.A.; Aguilera, R.V.; Lópezpuertas-Lamy, M.; Crespi, R. A clash of governance logics: Foreign ownership and board monitoring. Strateg. Manag. J. 2016, 37, 349-369. [CrossRef]

11. Brickley, J.A.; Coles, J.L.; Jarrell, G. Leadership structure: Separating the CEO and Chairman of the Board. J. Corp. Financ. 1997, 3, 189-220. [CrossRef]

12. Singh, S.; Tabassum, N.; Darwish, T.K.; Batsakis, G. Corporate Governance and Tobin's Q as a Measure of Organizational Performance. Br. J. Manag. 2018, 29, 171-190. [CrossRef]

13. Liao, L.; Lin, T.P.; Zhang, Y. Corporate board and corporate social responsibility assurance: Evidence from China. J. Bus. Ethics 2018, 150, 211-225. [CrossRef]

14. Adithipyangkul, P.; Leung, T.Y. Incentive pay for non-executive directors: The direct and interaction effects on firm performance. Asia Pac. J. Manag. 2018, 35, 943-964. [CrossRef]

15. Goyal, V.K.; Park, C.W. Board leadership structure and CEO turnove. J. Corp. Financ. 2002, 8, 49-66. [CrossRef]

16. Dalton, D.R.; Dalton, C.M. Integration of micro and macro studies in governance research: CEO duality, board composition, and financial performance. J. Manag. 2011, 37, 404-411. [CrossRef]

17. Cheng, X.; Smith, D.; Tanyi, P. An analysis of proxy statement leadership structure justification disclosures. Rev. Quant. Financ. Account. 2018, 51, 1071-1106. [CrossRef]

18. Din, H.R.; Liang, W.J. Patent Licensing in a Leadership Structure: Comment. Manch. Sch. 2013, 81, 332-339. [CrossRef]

19. Zona, F. Board leadership structure and diversity over CEO time in office: A test of the evolutionary perspective on Italian firms. Eur. Manag. J. 2014, 32, 672-681. [CrossRef]

20. Yasser, Q.R.; Mamun, A.A. The relationship between board leadership structure and earnings management in Asia-Pacific. Acc. Res. J. 2017, 29, 413-428. [CrossRef]

21. Aylin, A. Performance sensitivity of executive pay: The role of ownership structure, board leadership structure and board characteristics. Econ. Res. Ekon. Istraz. 2018, 31, 1152-1168.

22. Miller, S.; Yang, T. Board Leadership Structure of Publicly-Traded Insurance Companies. J. Insur. Issues 2015, 38, 184-232.

23. Davis, J.H.; Schoorman, F.D.; Donaldson, L. Toward a stewardship theory of management. Acad. Manag. Rev. 1997, 22, 20-47. [CrossRef]

24. Chen, S.H. The influencing factors of enterprise sustainable innovation: An empirical study. Sustainability 2016, 8, 425. [CrossRef]

25. Chen, Y.M.; Liu, H.H.; Yang, Y.K.; Chen, W.H. CEO succession in family firms: Stewardship perspective in the pre-succession context. J. Bus. Res. 2016, 69, 5111-5116. [CrossRef]

26. Haynes, K.T.; Hillman, A. The effect of board capital and CEO power on strategic change. Strateg. Manag. J. 2010, 31, 1145-1163. [CrossRef]

27. Keay, A. Stewardship theory: Is board accountability necessary? Int. J. Law Manag. 2016, 59, $1292-1314$. [CrossRef]

28. Ashwin, A.S.; Krishnan, R.T.; George, R. Family firms in India: Family involvement, innovation and agency and stewardship behaviors. Asia Pac. J. Manag. 2015, 32, 869-900. [CrossRef]

29. Zhang, F.; Wei, L.; Yang, J.; Zhu, L. Roles of Relationships between Large Shareholders and Managers in Radical Innovation: A Stewardship Theory Perspective. J. Prod. Innov. Manag. 2018, 35, 88-105. [CrossRef]

30. Faleye, O. Does one hat fit all? The case of corporate leadership structure. J. Manag. Gov. 2007, 11, 239-259. [CrossRef]

31. Yermack, D. Remuneration, Retention, and Reputation Incentives for Outside Directors. J. Financ. 2004, 59, 2281-2308. [CrossRef] 
32. Bebchuk, L.A.; Fried, J.M. Executive compensation as an agency problem. J. Econ. Perspect. 2003, 17, 71-92. [CrossRef]

33. Brick, I.E.; Palmon, O.; Wald, J.K. CEO compensation, director compensation, and firm performance: Evidence of cronyism? J. Corp. Financ. 2006, 12, 403-423. [CrossRef]

34. Lahlou, I.; Navatte, P. Director compensation incentives and acquisition performance. Int. Rev. Financ. Anal. 2017, 53, 1-11. [CrossRef]

35. Becher, D.A.; Campbell, T.L.; Frye, M.B. Incentive compensation for bank directors: The impact of deregulation. J. Bus. 2003, 78, 1753-1778. [CrossRef]

36. Eric, F. Board Holdings, Compensation and Mutual Fund Manager Turnover. J. Financ. Serv. Res. 2015, 47, 295-312.

37. Martikainen, M.; Kinnunen, J.; Miihkinen, A.; Troberg, P. Board's financial incentives, competence, and firm risk disclosure. J. Appl. Account. Res. 2015, 16, 333-358. [CrossRef]

38. Nyberg, P.; Pöyry, S. Firm expansion and stock price momentum. Rev. Financ. 2014, 18, 1465-1505. [CrossRef]

39. Smeds, R.; Boer, H. Continuous innovation and learning in industrial organizations. Knowl. Process Manag. 2004, 11, 225-227. [CrossRef]

40. Lin, C.Y.; Kuo, T.H. The mediate effect of learning and knowledge on organizational performance. Ind. Manag. Data Syst. 2007, 107, 1066-1083. [CrossRef]

41. Boons, F.; Montalvo, C.; Quist, J.; Wagner, M. Sustainable innovation, business models and economic performance: An overview. J. Clean. Prod. 2013, 45, 1-8. [CrossRef]

42. Calantone, R.J.; Cavusgil, S.T.; Zhao, Y. Learning orientation, firm innovation capability, and firm performance. Ind. Mark. Manag. 2002, 31, 515-524. [CrossRef]

43. Migdadi, M.M.; Zaid, M.K.A.; Yousif, M.; Almestarihi, R.D.; Al-Hyari, K. An Empirical Examination of Knowledge Management Processes and Market Orientation, Innovation Capability, and Organisational Performance: Insights from Jordan. J. Inf. Knowl. Manag. 2017, 16, 1-32. [CrossRef]

44. Peng, M.W.; Li, Y.; Xie, E.; Su, Z. CEO duality, organizational slack, and firm performance in China. Asia Pac. J. Manag. 2010, 27, 611-624. [CrossRef]

45. Martin, J.A.; Butle, F.C. Agent and stewardship behavior: How do they differ? J. Manag. Organ. 2017, 23, 633-646. [CrossRef]

46. Faleye, O. CEO directors, executive incentives, and corporate strategic initiatives. J. Financ. Res. 2011, 34, 241-277. [CrossRef]

47. Sher, P.J.; Yang, P.Y. The effects of innovative capabilities and R\&D clustering on firm performance: The evidence of Taiwan's semiconductor industry. Technovation 2005, 25, 33-43.

48. Fu, T.W.; Ke, M.C.; Huang, Y.S. Capital growth, financing source and profitability of small businesses: Evidence from Taiwan small enterprises. Small Bus. Econ. 2002, 18, 257-267. [CrossRef]

49. Nkundabanyanga, S.K. Board governance, intellectual capital and firm performance: Importance of multiplicative effects. J. Econ. Adm. Sci. 2016, 32, 20-45. [CrossRef]

50. Seijts, G.; Byrne, A.; Crossan, M.M.; Gandz, J. Leader character in board governance. J. Manag. Gov. 2018, 7, $1-32$.

51. Kang, E.; Zardkoohi, A. Board leadership structure and firm performance. Corp. Gov. 2005, 13, 785-799. [CrossRef]

52. Aktas, N.; Andreou, P.C.; Karasamani, I.; Philip, D. CEO Duality, Agency Costs, and Internal Capital Allocation Efficiency. Br. J. Manag. 2018, 1, 1-21. [CrossRef]

53. Doucouliagos, H.; Haman, J.; Askary, S. Directors' remuneration and performance in Australian banking. Corp. Gov. 2007, 15, 1363-1383. [CrossRef]

54. Ketata, I.; Sofka, W.; Grimpe, C. The role of internal capabilities and firms' environment for sustainable innovation: Evidence for Germany. Res. Dev. Manag. 2014, 45, 60-75. [CrossRef]

55. Hall, R. A framework linking intangible resources and capabiliites to sustainable competitive advantage. Strateg. Manag. J. 1993, 14, 607-618. [CrossRef]

56. Den Hertog, P.; Bilderbeek, R.; Maltha, S. Intangibles: The soft side of innovation. Futures 1997, $29,33-45$. [CrossRef]

57. Artz, K.W.; Norman, P.M.; Hatfield, D.E.; Cardinal, L.B. A longitudinal study of the impact of R\&D, patents, and product innovation on firm performance. J. Prod. Innov. Manag. 2010, 27, 725-740. 
58. Anadon, L.D.; Chan, G.; Harley, A.G.; Matus, K.; Moon, S.; Murthy, S.L.; Clark, W.C. Making technological innovation work for sustainable development. Proc. Natl Acad. Sci. USA 2016, 113, 9682-9690. [CrossRef] [PubMed]

59. Brem, A.; Nylund, P.A.; Hitchen, E.L. Open innovation and intellectual property rights: How do SMEs benefit from patents, industrial designs, trademarks and copyrights? Manag. Decis. 2017, 55, 1285-1306. [CrossRef]

60. Kung, J.K.; Ma, C. Friends with benefits: How political connections help to sustain private enterprise growth in China. Economica 2018, 85, 41-74. [CrossRef]

61. Cho, S.J.; Chung, C.Y.; Young, J. Study on the Relationship between CSR and Financial Performance. Sustainability 2019, 11, 343. [CrossRef]

62. Leal-Rodríguez, A.L.; Eldridge, S.; Roldán, J.L.; Leal-Millán, A.G.; Ortega-Gutiérrez, J. Organizational unlearning, innovation outcomes, and performance: The moderating effect of firm size. J. Bus. Res. 2015, 68, 803-809.

63. Cenni, S.; Monferrà, S.; Salotti, V.; Sangiorgi, M.; Torluccio, G. Credit rationing and relationship lending. Does firm size matter? J. Bank. Financ. 2015, 53, 249-265. [CrossRef]

64. Choi, B.; Kumar, M.V.S.; Zambuto, F. Capital structure and innovation trajectory: The role of debt in balancing exploration and exploitation. Organ. Sci. 2016, 27, 1183-1201. [CrossRef]

65. Bozec, Y.; Bozec, R. Ownership concentration and corporate governance practices: Substitution or expropriation effects? Can. J. Adm. Sci. 2007, 24, 182-195. [CrossRef]

66. Haynes, M.; Thompson, S.; Wright, M. Executive remuneration and corporate divestment: Motivating managers to make unpalatable decisions. J. Bus. Financ. Account. 2007, 34, 792-818. [CrossRef]

67. Ahlstrom, D. Innovation and growth: How business contributes to society. Acad. Manag. Perspect. 2010, 24, 11-24.

68. Ahmed, S.; Coulibaly, B.; Zlate, A. International financial spillovers to emerging market economies: How important are economic fundamentals? J. Int. Money Financ. 2017, 76, 133-152. [CrossRef]

69. Neumayer, E.; Plümper, T. Robustness Tests for Quantitative Research; Cambridge University Press: Cambridge, UK, 2017.

70. Nieto, M.J.; Santamaria, L.; Fernandez, Z. Understanding the innovation behavior of family firms. J. Small Bus. Manag. 2015, 53, 382-399. [CrossRef]

71. Wu, C.H.; Parker, S.K.; De Jong, J.P.J. Need for cognition as an antecedent of individual innovation behavior. J. Manag. 2014, 40, 1511-1534. [CrossRef]

72. Widya-Hasuti, A.; Mardani, A.; Streimikiene, D.; Sharifara, A. The role of process innovation between firm-specific capabilities and sustainable innovation in SMEs: Empirical evidence from indonesia. Sustainability 2018, 10, 2244. [CrossRef]

73. Su, D. State ownership, corporate tournament and executive compensation: Evidence from public listed firms in China. Singap. Econ. Rev. 2011, 56, 307-326. [CrossRef]

74. Honghui, Z.; Jiaying, H.H.; Ahsan, H. The Effect of Tournament Incentives on Financial Restatements: Evidence from China. Int. J. Account. 2018, 53, 118-135.

(C) 2019 by the authors. Licensee MDPI, Basel, Switzerland. This article is an open access article distributed under the terms and conditions of the Creative Commons Attribution (CC BY) license (http://creativecommons.org/licenses/by/4.0/). 